\title{
TTR
}

Traduction, terminologie, re?daction

\section{Genealogies of Translation Theory: Schleiermacher}

\section{Lawrence Venuti}

Volume 4, numéro 2, 2e semestre 1991

Traduire la théorie

URI : https://id.erudit.org/iderudit/037096ar

DOI : https://doi.org/10.7202/037096ar

Aller au sommaire du numéro

Éditeur(s)

Association canadienne de traductologie

ISSN

0835-8443 (imprimé)

1708-2188 (numérique)

Découvrir la revue

Citer cet article

Venuti, L. (1991). Genealogies of Translation Theory: Schleiermacher. TTR, 4(2), 125-150. https://doi.org/10.7202/037096ar d'utilisation que vous pouvez consulter en ligne.

https://apropos.erudit.org/fr/usagers/politique-dutilisation/ 


\section{Genealogies of Translation Theory: Schleiermacher}

\section{Lawrence Venuti}

The genealogical method in Nietzsche and Foucault enables the formulation of a political agenda in cultural history by abandoning two principles that govern much conventional historiography: teleology and objectivity. Genealogy is a form of historical representation that depicts, not a continuous progression from a unified origin, an inevitable development in which the past fixes the meaning of the present, but a discontinuous succession of division and hierarchy, domination and exclusion, which destabilize the seeming unity of the present by constituting a past with plural, heterogeneous meanings. In a genealogical analysis, writes Foucault, "what is found at the historical beginnings of things is not the inviolable identity of their origin; it is the dissension of other things. It is disparity." (p. 142) The possibility of recuperating these "other" meanings explodes the pretense of objectivity in conventional historiography: its teleological emphasis betrays a complicity with the continuance of past domination and exclusion into the present. Thus, history is shown to be a cultural political practice, a partial (i.e., at once selective and evaluative) representation of the past that actively intervenes into the present, even

1. The key statement is Michel Foucault, "Niezzsche, Genealogy, History." Language, Counter-Memory, Practice: Selected Essays and Interviews, ed. and trans. Donald F. Bouchard and Sherry Simon (Ithaca, New York, Comell University Press, 1977), pp. 139-164. See also the commentary in Hubert L. Dreyfus and Paul Rabinow, Michel Foucault: Beyond Structuralism and Hermeneutics, 2nd ed. (Chicago, University of Chicago Press, 1983), pp. 104-125. 
if the interests served by that intervention are not made explicit or perhaps remain unconscious. For Foucault, a genealogical analysis is unique in affirming the interested nature of its historical representation, in taking a stand vis-à-vis the political struggles of its situation. And by locating what has been dominated or excluded in the past and repressed by conventional historiography, such an analysis can not only challenge the cultural and social conditions in which it is performed, but propose different conditions to be established in the future. History informed by genealogy, Foucault suggests, "should become a differential knowledge of energies and failings, heights and degenerations, poisons and antidotes. Its task is to become a curative science." (p. 156) By constructing a differential representation of the past, genealogy both engages in present social conflicts and develops resolutions that project utopian images.

The urgency to make translation theory and practice the object of a genealogical analysis comes from the ascendancy of transparent discourse in contemporary translation. A translated text is judged successful - by editors, publishers, reviewers, readers, by translators themselves - when it reads fluently and thereby gives the appearance that it is not translated, that it is the original, reflecting the foreign author's personality or intention or the essential meaning of the foreign text. $^{2}$ A fluent translation strategy produces the effect of transparency by foregrounding the conceptual signified and minimizing any disruptive play of signifiers, pursuing linear syntax, univocal meaning, current usage, linguistic consistency. At the same time, however, fluency results in an effacement of the multiple determinations and effects of translation. It aims to mask the translator's decisive rewriting of the foreign text in accordance with a strict regimen of self-erasure, utter invisibility, usually in the name of "fidelity," but always at the translator's expense: the production of a transparent discourse inevitably contributes to the cultural marginality and economic exploitation that translators suffer everywhere today. Fluency is a translation strategy that conceals its own textual and social work, its hypertextuality and its social effectivity, not only home, but abroad, in relation to a cultural other. It masks the linguistic and cultural

2. I discuss this issue at greater length in "The Translator's Invisibility," Criticism, 28 (1986), pp. 179-212. 
difference of the foreign text, the intricate affiliations with a different time and place, but also its own construction of an identity for the foreign culture mediated by target-language values - like transparent discourse. The fluent strategies that dominate contemporary AngloAmerican and French cultures (among others) limit the selection of foreign texts to be translated by favoring transparency; and when such strategies are implemented, they inescapably perform a work of acculturation, in which a cultural other is domesticated, made intelligible, but also familiar, even the same, encoded as it is with ideological cultural discourses circulating in the target language. Fluency exemplifies in an extreme and particularly troubling form the ethnocentric and imperialist movements that necessarily figure in every act of translation, raising questions about the role of translation patterns and practices in current geopolitical conflicts. ${ }^{3}$ A genealogical analysis of translation can intervene against the contemporary dominance of fluent strategies by searching the past for exits, alternative theories and practices that question the valorization of transparency and seek to construe translation as the locus of cultural difference, not homogeneity.

Antoine Berman has already taken an important step in this direction by articulating a translation ethics. Against the contemporary ascendancy of fluent, ethnocentric translation, Berman invokes Emmanuel Levinas's ethics of the other - "L'acte éthique consiste a reconnaître et à recevoir l'Autre en tant qu'Autre" - and then redefines the translation topos of fidelity as the "désir d'ouvrir l'Étranger en tant qu'Étranger à son propre espace de langage." Translation is conceived, not as the communication of a cultural other - any representation is always an inscription of its object - but as a manifestation that reveals the foreign in a determinate form: "La visée éthique, poétique et

3. Edward Said, for example, considers the political implications of the marginality of Arabic literature in Anglo-American translation, see "Embargoed Literature," The Nation, 17 September 1990, pp. 278280.

4. Antoine Berman, "La traduction et la lettre, ou l'auberge du lointain," in Les Tours de Babel: Essais sur la traduction (Mauvezin, TransEurop-Repress, 1985), pp. 35-150 (88-89). Hereafter designated as $T L$ in the text. 
philosophique de la traduction consiste à manifester dans sa langue cette pure nouveauté en préservant son visage de nouveauté. Et même, comme disait Goethe, à lui donner une nouvelle nouveauté lorsque son effet de nouveauté s'est épuisé dans sa propre aire langagière" (TL, p. 89). The ethical translation manifests an autre, étrangere nouveauté, but only within the discursive formation in the target-language culture.

This thinking provides the impetus for Berman's incisive reconstruction of the German translation tradition, particularly the romantic period, where he treats Friedrich Schleiermacher's lecture Ueber die verschiedenen Methoden des Uebersetzens (1813) as a key "reflexion sur la traduction fondée sur des valeurs éthiques." In Berman's oppositional tradition-building, Schleiermacher emerges as an antidote to the present, but only as an antidote: Berman's genealogy stops short of developing a truly differential historicism that mobilizes both the poisons and antidotes of the past against the current situation. In fact, Berman finds no poisons in Schleiermacher: he offers a rather deferential treatment that emphasizes what is "moderne" in Schleiermacher's translation theory - "le fondateur de cette herméneutique moderne" - and how it can be seen as answering the difficult questions posed by ethnocentric translation in the present. Since these are not questions that Schleiermacher explicitly addresses, they wind up deferring what is historically specific in his lecture, the heterogeneous cultural and social conditions to which it responds in Napoleonic Germany. And this deferral of Schleiermacher's historical difference limits the capacity of his thinking to make a cultural and social difference today. A genealogical analysis needs to show how Schleiermacher's lecture negates contemporary translation, not merely by resolving its problems and conflicts, but by decentering and revising them, forcing the articulation of new concepts, strategies, agendas, really poisoning present translation practices so as to (re)vivify others. Next to Berman's reading of Schleiermacher as the "radical" critic of ethnocentric translation, we must set a more differential knowledge of his bourgeois cultural elitism and Prussian nationalism, showing how he

5. Antoine Berman, L'Épreuve de l'étranger: Culture et traduction dans l'Allemagne romantique (Paris, Gallimard, 1984), p. 242. Hereafter designated as $E E$ in the text. 
already initiates a shift from an ethical to a political problematic in current debates about translation.

For Schleiermacher, "the genuine translator" is a writer "who wants to bring those two completely separated persons, his author and his reader, truly together, and who would like to bring the latter to an understanding and enjoyment of the former as correct and complete as possible without inviting him to leave the sphere of his mother

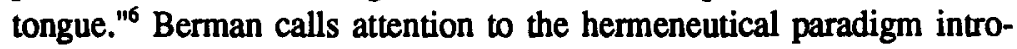
duced here, the emphasis on translation as the object of textual interpretation that enables intersubjective understanding, "un processus de rencontre intersubjectif" (EE, p. 235). And this makes communication the criterion by which methodological choices are validated and authentic translation distinguished from inauthentic. Schleiermacher in fact finds only two methods of effecting the targetlanguage reader's understanding of the source-language "author": "Either the translator leaves the author in peace, as much as possible, and moves the reader towards him; or he leaves the reader in peace, as much as possible, and moves the author towards him" (p. 74). Schleiermacher privileges the first method, making the target-language reader travel abroad, and Berman reads it as an ethical move that "procède à une critique radicale (pour son époque) de la traduction ethnocentrique et hypertextuelle" (TL, p. 91). Yet Schleiermacher's methodological distinction can be radical in this sense only pour notre epoque, since he doesn't describe the authentic translator's "aim" in ethical terms; rather, his terms are social, with translation offering an understanding of the foreign text which is not merely ethnocentric, but relative to a specific social group:

6. English renderings of Schleiermacher's lecture are taken from "On the Different Methods of Translating," in Translating Literature: The German Tradition from Luther to Rosenzweig, ed. and trans. André Lefevere (Assen, Van Gorcum, 1977), pp. 67-89. French renderings are from "Des différentes méthodes du traduire," trans. Antoine Berman, in Les Tours de Babel, pp. 279-347. Berman's translation is printed with the German text en face. The German follows Friedrich Schleiermacher, Sämmitliche Werke, Dritte abteilung: Zur Philosophie, Zweiter Band (Berlin, Reimer, 1838), pp. 207-245. 
[...] the translator must therefore take as his aim to give his reader the same image and the same delight which the reading of the work in the original language would afford any reader educated in such a way that we call him, in the better sense of the word, the lover and the expert ["Leibhaber und Kenner/amateur et connaisseur" ( $T L$, pp. 306-307)], the type of reader who is familiar with the foreign language while it yet always remains foreign to him: he no longer has to think every single part in his mother tongue, as schoolboys do, before he can grasp the whole, but he is still conscious of the difference between that language and his mother tongue, even where he enjoys the beauty of the foreign work in total peace. (p. 76)

The translator aims to preserve the linguistic and cultural difference of the foreign text, but only as it is perceived in the translation by a limited readership, an educated elite. This means, first, that translation is always ethnocentric: even when a translated text contains discursive peculiarities designed to imitate a foreign text, even when the translation seems, in Schleiermacher's (English translator's) words, "bent toward a foreign likeness" (pp. 78-79; "zu einer fremden Aehnlichkeit hinübergebogen" [TL, p. 314]), it never escapes the hierarchy of cultural values inscribed in the target language. These values mediate every move in the translation and every target-language reader's response to it, including the perception of what is domestic or foreign: André Lefevere's English version - "bent toward a foreign likeness" - domesticates Schleiermacher's German by submitting its syntax to the dominant fluent strategy, whereas "toward a foreign likeness bent," a discursive peculiarity that resists fluency by marking the English translation as archaic for the contemporary Anglo-American reader, foreignizes the English by bending it toward the German syntax. Schleiermacher's theory anticipate this point: he is keenly aware that translation strategies are situated in specific cultural formations where discourses are canonized or marginalized, circulating in relations of domination and exclusion. Thus, the translation method that cultivates discursive peculiarities to imitate the foreignness of the foreign text "cannot thrive equally well in all languages, but only in those which are not the captives of too strict a bond of classical expression outside of which all is reprehensible"; the ideal site for the privileged method is 
"languages which are freer, in which innovations and deviations are tolerated to a greater extent, in such a way that their accumulation may, under certain circumstances, generate a certain characteristic mode of expression" (pp. 79-80). This linguistic and cultural freedom is complexly determined: not only is it defined against the "bonded languages" of other national cultures, but the "innovations and deviations" that manifest it are defined against the norm set by other, dominant discourses in the target-language culture. The innovations and deviations produced in Schleiermacher's foreignizing translation are signs of "a foreign likeness"; and since his advocacy of this method is also an advocacy of discourses specific to an educated elite, he invests this limited social group with considerable cultural authority, going so far as to assign it a precise social function - to "generate a certain characteristic mode of expression," developing a national language, "influencing the whole evolution of a culture" (pp. 80-81; "die gesammte Geistesentwikkelung" [TL, p. 322]). Schleiermacher is enlisting his privileged translation method in a cultural political agenda, wherein an educated elite controls the formation of a national culture by refining its language through foreignizing translations.

Schleiermacher's lecture permits a much more detailed social and historical specification of this agenda. He concludes with some explicit references to "we Germans," remarking that "our nation," "because of its respect for what is foreign and its mediating nature" (p. 88; "seiner vermittelnden Natur" [TL, p. 344]), uniquely satisfies the "two conditions" necessary for foreignizing translation to thrive, namely "that understanding foreign works should be a thing known and desired and that the native language should be allowed a certain flexibility" (p. 81). This is the understanding of foreign works sought by educated "Germans" like Schleiermacher, a university professor and minister in the Reformed church, who feels that the German language possesses the "flexibility" to support foreignizing translation since it is undeveloped, lacking a definite "mode of expression," not yet "bonded" to the "classical," a "partial mother tongue": "our language, because we exercise it less owing to our Nordic sluggishness, can thrive in all its freshness and completely develop its own power only through the most many-sided contacts with what is foreign" (p. 88). Since the category "foreign" here is determined by the educated, Schleiermacher is using 
translation to mark out a dominant space for a bourgeois minority in early nineteenth-century German culture.

As Albert Ward observes of this period, "literature was [...] a predominantly bourgeois art, but it was only a small part of this section of the community that responded most readily to the classical writers of the great age of German literature. [...] Writers like Goethe and Schiller found their public in the Honoratioren of the large towns, in the university-trained professional men, the ministers of religion, teachers, doctors, and lawyers, in what might be termed the elite of middle-class society. 'High literature' was then even more than now a thing for a small group of scholars." Ward's historical reconstruction demonstrates the cultural and economic marginality of German "literature," both classical and romantic, by referring to sizes of editions and sales figures amid some striking testimonies from contemporaries in the publishing industry: "Karl Preusker, who came to Leipzig as a bookseller's apprentice in 1805, names in his autobiography the authors most in demand at that time; the most classical (as we understand the term today) of the authors on his list is Zschokke, "whereas the works of Schiller and Goethe were sold in only meager quantities'" (p. 132). Schleiermacher, who associated with the leading German romantics, briefly shared a Berlin apartment with Friedrich Schlegel, and contributed to the Schlegel brothers' small-circulation journal, the Athenaeum, was entirely in agreement with Goethe when developing his theory of foreignizing translation. In an essay on "Wieland's brotherly memory" published in 1813, four months before Schleiermacher's lecture, Goethe wrote:

there are two maxims in translation: one requires that the author of a foreign nation be brought across to us in such a way that we can look on him as ours; the other requires that we should go across to what is foreign and adapt ourselves to its conditions, its use of language, its peculiarities. The

7. Albert Ward, Book Production, Fiction and the German Reading Public, 1740-1800 (Oxford, Oxford University Press, 1974), p. 128. James J. Sheehan surveys the different German cultural constituencies during this period in German History, 1770-1866 (Oxford, Oxford University Press, 1989), especially pp. 157-158. 
advantages of both are sufficiently known to educated people through perfect examples. Our friend, who looked for the middle way in this, too, tried to reconcile both, but as a man of feeling and taste he preferred the first maxim when in doubt. $^{8}$

In siding with this "feeling and taste" for "what is foreign," Schleiermacher is valorizing an elitist bourgeois cultural discourse of literary refinement against the larger, more heterogeneous culture of the middle and working classes. "The average middle-class reader," Ward points out, "wanted works which were within his own experience and range of emotion, reflecting his own interests and not conflicting with the demands of his morality" (p. 133). Whereas Schleiermacher's lecture on translation is quite scholarly in citing only Greek and Latin writing (Plato, Cicero, Tacitus, Grotius, and Leibniz), the wider middleclass readership favored Gothic tales, chivalric romances, realistic novels both sentimental and didactic, biographies of exemplary men, travel literature. This audience was reading translations as well, but the greatest percentage of them were translations of French and English novels, including the work of Choderlos de Laclos and Richardson. Schleiermacher himself had translated Plato, while other romantics Voss, August Wilhelm Schlegel, Holderlin - translated Sophocles, Homer, Dante, and Shakespeare. They were very much aware that they were translating for a relatively narrow audience, even a coterie, and like Schleiermacher, they saw this social fact as a value that improved their "literature" and endowed it with cultural authority. Friedrich Schlegel boasted that "[readers] are for ever complaining that German authors write for such a small circle, often in fact for themselves as a group. I find this a good thing. German literature gains more and more in spirit and character because of it." (Ward, p. 191, n. 46)

Schlegel's comment shows that this is not only a bourgeois, but a nationalist concept of literature - "German." And Schleiermacher's theory of foreignizing translation reveals a similar ideological

8. Johann Wolfgang Goethe, "Zum bruderlichen Andenken Wielands," in Translating Literature: The German Tradition, ed. and trans. André Lefevere, p. 39. Goethe's essay was published 18 February 1813. 
configuration: it is also pitched against a German nobility that was not literary and had long lain under French cultural domination. Aristocratic culture eschewed scholarly research and wide reading in past and contemporary literature; "the few courts which did take an active interest in literary affairs," Ward notes, "were characterized by a predominantly bourgeois atmosphere" (p. 128). In aristocratic education, "the accent was on languages, particularly French, and often to such an extent that many noblemen could express themselves better in that language than in their mother tongue" (p. 123). In a letter from 1757, the aesthetician and dramatist Johann Christoph Gottsched described an audience with Frederick II, during which he informed the Prussian king of the serious threat to literary culture posed by the Gallicized nobility:

When I said that German writers did not receive sufficient encouragement, as the aristocracy and the courts spoke too much French and understood too little German to be able to grasp and appreciate fully anything written in German, He said: that is true, for I haven't read no German book since my youth, and je parle comme un cocher, but now I am an old fellow of forty-six and have not time for such things. (Ward, p. 190n)

Some fifty years later, Schleiermacher's lecture on translation engages in the cultural struggle for a German literature with an equally bold criticism of Frederick II. Yet he represents the king, not as Gottsched's anti-intellectual oaf, but as a German intellect limited by his utter dependence on French:

Our great king received all his finer and higher thoughts in a foreign language, which he had most intimately appropriated for this field. He was incapable of producing in German the literature and philosophy he produced in French. It is to be deplored that the great preference for England which dominated a part of the family could not have taken the direction of familiarizing him from childhood on with the English language, whose last golden age was then in bloom, and which is so much closer to German. But we may hope that he would have preferred to produce literature and 
philosophy in Latin, rather than in French, if he had enjoyed a strict scholarly education. (p. 83)

Here the nationalist dimension of Schleiermacher's cultural politics becomes more clear: the king is taken to task not so much because he is not "scholarly" (he is in fact portrayed as being genuinely interested in "literature and philosophy"), but because he doesn't write in German, or in a language "closer to German" than French. Whereas Gottsched seems to be lamenting the dearth of literary patronage ("sufficient encouragement") because the Prussian aristocracy is Francophone, Schleiermacher is more concerned about the unequal cultural production in German and French: "He was incapable of producing in German."

Schleiermacher's criticism of the king is a nationalist protest against French domination in Germany, and it is consistent with his intense activity in the Prussian movement for German unification during the Napoleonic wars. As Jerry Dawson makes clear, "the war between France and Prussia in 1806, with the resulting collapse of the Prussian armies and the huriiliating peace terms dictated to Prussia by Napoleon, proved to be the final factor needed to turn [Schleiermacher] to nationalism with a complete and almost reckless abandon." "Germany" did not actually exist at this time: west of the Rhine were several petty principalities, which, after 1806, Napoleon organized into a "confederation"; east was the dominant German-speaking monarchy, Prussia, now dominated by the French. The Prussian defeat caused Schleiermacher to lose his appointment at the University of Halle, and he fled to Berlin, the Prussian capital, where he lectured at the university and preached at various churches. His sermons urged political and military resistance against the French armies, developing a cultural concept of nationality based on the German language and legitimized with Protestant theology. In 1813, three months before his

9. Jerry Dawson, Friedrich Schleiermacher: The Evolution of a Nationalist (Austin and London, University of Texas Press, 1966), p. 51. Sheehan offers a survey of German nationalism in the eighteenth and early nineteenth century in German History, pp. 371388. See also Otto W. Johnston, The Myth of a Nation: Literature and Politics in Prussia under Napoleon (Columbia, South Carolina, Camden House, 1989), pp. 103-113. 
lecture on translation at the Berlin Akademie der Wissenschaften and eight months before Napoleon was finally defeated at the Battle of Leipzig, Schleiermacher delivered a sermon entitled "A Nation's Duty in a War for Freedom," wherein he represented the war with France as a struggle against cultural and political domination: if victorious, he exhorted the congregation, "we shall be able to preserve for ourselves our own distinctive character, our laws, our constitution and our culture. ${ }^{10}$ In June, the month of his lecture, Schleiermacher wrote a letter to Friedrich Schlegel in which his nationalism turned utopian: "My greatest wish after liberation, is for one true German Empire, powerfully representing the entire German folk and territory to the outside world, while internally allowing the various Länder and their princes a great deal of freedom to develop and rule according to their own particular needs." ${ }^{11}$ This vision of Germany as a union of relatively autonomous principalities is partly a compensation for the current international conflict, and actually it is somewhat backward-looking, traced with a nostalgia for the domestic political organization that prevailed before the French occupation: Napoleon introduced social innovations effected by the revolution, abolishing feudalism and promoting "enlightened" despotism in Prussia. Even though Schleiermacher himself was a member of a bourgeois cultural elite, his nationalist ideology is such that it admits aristocracy, monarchy, even an imperialist tendency - but only when they constitute a national unity resistant to foreign domination.

Presented to the Prussian academic establishment on 24 June 1813 , at the height of the conflict with France, Schleiermacher's lecture constructs a role for translation in a nationalist cultural politics. His theory of foreignizing translation should be seen as anti-French because it opposes the translation method that dominated France since neoclassicism, viz. domestication, making the foreign author travel abroad to the target-language reader. When surveying the limited acceptance of foreignizing translation in western culture, Schleiermacher reserves his most withering sarcasm for France: "The ancients

10. Friedrich Schleiermacher, Selected Sermons, trans. Mary F. Wilson (New York, Funk and Wagnalls, 1890), p. 73.

11. Quoted and translated by Sheehan, German History, p. 379. 
obviously translated little in that most real sense and most moderns, deterred by the difficulties of true translation, also seem to be satisfied with imitation and paraphrase. Who would want to contend that nothing has even been translated into French from the classical languages or from the Germanic languages! But even though we Germans are perfectly willing to listen to this advice, we should not follow it" (p. 88). French exemplifies those languages that are "captives of too strict a bond of classical expression outside of which all is reprehensible," especially the innovations and deviations introduced by foreignizing translation. In a satiric dialogue from 1798, A. W. Schlegel had already made explicit the nationalist ideology at work in identifying French culture with a domesticating translation method:

Frenchman: [...] the Germans translate every Tom, Dick, and Harry. We either do not translate at all, or else we translate according to our own taste.

German: Which is to say, you paraphrase and you disguise. Frenchman: We look on a foreign author as a stranger in our company, who has to dress and behave according to our customs, if he desires to please.

German: How narrow-minded of you to be pleased only by what is native.

Frenchman: Such is our nature and our education. Did the Greeks not hellenize everything as well?

German: In your case it goes back to a narrow-minded nature and a conventional education. In ours education is our nature. $^{12}$

12. August Wilhelm Schlegel, "Der Wettstreit der Sprachen," in Translating Literature: The German Tradition, ed. and trans. André Lefevere, p. 50. Lefevere's choice of "the Germans translate every literary Tom, Dick, and Harry" to render Schlegel's "die Deutschen sind ja Allerweltsubersetzer" is typical of his strong reliance on fluent strategies that draw on contemporary English idioms. The German text is included in August Wilhelm Schlegel, Kritische Schriften und Briefe I: Sprache und Poetik, ed. Edgar Lohner (Stuttgart, Kohlhammer, 1962), pp. 219-259 (252). 
Schlegel's dialogue indicates the metaphysical underpinnings of German nationalism, its assumption of a biological or racial essence from which the national culture issues: "education is our nature." This agrees both with Schleiermacher's view that "our nation" possesses a "mediating nature" and with the organic metaphor he uses to explain the German receptiveness to foreignizing translation:

Just as our soil itself has no doubt become richer and more fertile and our climate milder and more pleasant only after much transplantation of foreign flora, just so we sense that our language, because we exercise it less owing to our Nordic sluggishness, can thrive in all its freshness and completely develop its own power only through the most many-sided contacts with what is foreign. (p. 88)

Schleiermacher's nationalist theory of foreignizing translation aims to challenge French hegemony not only by enriching German culture, but by contributing to the formation of a liberal public sphere, an area of social life in which private individuals exchange rational discourse and exercise political influence:

If ever the time should come in which we have a public life out of which develops a sociability of greater merit and truer to language, and in which free space is gained for the talent of the orator, we shall be less in need of translation for the development of language. (p. 89)

Yet Schleiermacher's public sphere manifests the contradiction that characterized the concept from its emergence in eighteenth-century aesthetics. As Peter Uwe Hohendahl puts it, "although in principle the capacity to form an accurate opinion is considered present in everyone, in practice it is limited to the educated." ${ }^{13}$ So in Schleiermacher: although the work of foreignizing translation on the German language

13. Peter Uwe Hohendahl discusses the emergence of the literary public sphere in eighteenth-century England and Germany in "Literary Criticism and the Public Sphere," trans. Ronald L. Smith and Henry J. Schmidt, The Institution of Criticism (Ithaca, New York, Comell University Press, 1982), pp. 44-82. The quotation appears on p. 51. 
is seen as creating a national culture free of French political domination, this public space is open explicitly for "the talent of the orator," a literary elite. Because this is a strongly nationalist elite, it also employs foreignizing translation in a remarkable project of German cultural imperialism, through which the race "destined" for global domination achieves it. Here nationalism is equivalent to universalism:

An inner necessity, in which a peculiar calling of our people expresses itself clearly enough, has driven us to translating en masse; we cannot go back and we must go on. [...] And coincidentally our nation may be destined, because of its respect for what is foreign and its mediating nature, to carry all the treasures of foreign arts and scholarship, together with its own, in its language, to unite them into a great historical whole, so to speak, which would be preserved in the centre and heart of Europe, so that with the help of our language, whatever beauty the most different times have brought forth can be enjoyed by all people, as purely and perfectly as is possible for a foreigner. This appears indeed to be the real historical aim of translation in general, as we are used to it now. (p. 88)

Thus, readers of the canon of world literature would experience the linguistic and cultural difference of foreign texts, but only as a difference that is Eurocentric, mediated by a German bourgeois elite. Ultimately, it would seem that foreignizing translation does not so much introduce the foreign into German culture as use the foreign to confirm and develop a sameness, a process of fashioning an ideal cultural self on the basis of an other, a cultural narcissism, which is endowed, moreover, with historical necessity. This method of translation "makes sense and is of value only to a nation that has the definite inclination to appropriate what is foreign" (p. 80). The ideological ensemble in Schleiermacher's cultural politics precipitates contradictory permutations (elite literature/national culture, bourgeois minority/"Germany," foreignizing/Germanizing), so we should not be surprised to find him speaking for and against foreign imports in German culture - in that same turbulent year, 1813. His bourgeois nationalism shapes both his advocacy of "many-sided contacts with the foreign" in the translation lecture and his xenophobic condescension in the patriotic sermon: 
"Every nation, my dear friends, which had developed a particular, or clearly defined height is degraded also by receiving into it a foreign element." ${ }^{14}$ This assumes, contrary to the lecture, that German culture has already attained a high level of development, presumably in classical and romantic literature, which must be protected from foreign contamination and imposed universally, through a specifically German foreignization of world literature. Schleiermacher's translation theory intervenes in "die gesammte Geistesentwikkelung," a phrase that may seem restricted nationally in Lefevere's English, "the whole evolution of a culture" (p. 81), but is shown to have worldwide application in Berman's French: "le processus global de la formation de l'esprit" (TL, pp. 322, 333). And only Berman discloses the idealist metaphysics at work in the German text by choosing "esprit" for "Geist."

Berman's own translation thus shows that Schleiermacher's theory is shaky ground on which to build a translation ethics to combat ethnocentrism: the lecture does not recognize any contradiction in asserting that "our nation" is distinguished by "respect for what is foreign" while envisioning the geopolitical domination of a German bourgeois cultural elite. It also does not recognize antinomies in its thinking about language and human subjectivity which are likewise determined by bourgeois nationalism. The "proper field" of the translator, Schleiermacher states, consists of "those mental products of scholarship and art in which the free idiosyncratic combinatory powers of the author and the spirit of the language which is the repository of a system of observations and shades of moods are everything, in which the object no longer dominates in any way, but is dominated by thoughts and emotions, in which, indeed, the object has become object only through speech and is present only in conjunction with speech" (pp. 69-70). Schleiermacher evinces an extraordinarily clear sense of the constitutive properties of language, those that make representation always an appropriative activity, never transparent or merely adequate to its object, and that figure in the construction of subjectivity by establishing forms for consciousness. At the same time, however, his concept of "free idiosyncratic combinatory powers" signals a move toward an autonomous subject whose "thoughts and emotions" transcend

14. Schleiermacher, Selected Sermons, pp. 73-74. 
linguistic determinations. "On the one hand," Schleiermacher asserts, "every man is in the power of the language he speaks, and all his thinking is a product thereof. [...] Yet on the other hand every freely thinking, mentally self-employed human being shapes his own language. [...] Therefore each free and higher speech needs to be understood twice, once out of the spirit of the language of whose elements it is composed, as a living representation bound and defined by that spirit and conceived out of it in the speaker, and once out of the speaker's emotions, as his action, as produced and explicable only out of his own being" (p. 71). The "spirit of the language" determines every speech act, is binding on every subject, but part of that action nevertheless answers only to an individual "being." At one point, the priority of language over subject is tellingly reversed, with the author becoming the sole origin of the "spirit": the readers of a foreignizing translation are said to "understand" when they "perceive the spirit of the language which was the author's own and [are] able to see his peculiar way of thinking and feeling" (p. 72). As Berman points out, Schleiermacher's lecture manifests the late eighteenth-century shift from representation to expression as the paradigm for language use, and hence subject displaces object as the basis of interpretation ( $E E$, p. 233). Schleiermacher's thinking about language is informed by romantic expressive theory, grounded in the concept of the free, unified consciousness that characterizes bourgeois individualism. ${ }^{15}$

As his exposition proceeds, it turns to metaphor and illustration, defining the "spirit of the language" in racial terms, yet without abandoning the transcendental subject:

We understand the spoken word as an act of the speaker only when we feel at the same time where and how the power of language has taken hold of him, where in its current the lightning of thought has uncoiled, snake-like, where and how

15. For romantic expressive theory, see M. H. Abrams, The Mirror and the Lamp: Romantic Theory and the Critical Tradition (Oxford, Oxford University Press, 1953). The most devastating critique of this theory remains Jacques Derrida, Of Grammatology, trans. Gayatri Chakravorty Spivak (Baltimore and London, Johns Hopkins University Press, 1976). 
the roving imagination has been held firm in its forms. We understand the spoken word as a product of language and as an expression of its spirit only when we feel that only a Greek, for instance, could think and speak in that way, that only this particular language could operate in a human mind this way, and when we feel at the same time that only this man could think and speak in the Greek fashion in this way, that only he could seize and shape the language in this manner, that only his living possession of the riches of language reveals itself like this, an alert sense for measure and euphony which belongs to him alone, a power of thinking and shaping which is peculiarly his. (p. 72)

The metaphors - "lightning," "snake-like," "roving" - continue the individualistic strain by depicting the subject as a coherent essence, radically independent of language, given to serpentine, potentially subversive "thought," possessing a free "imagination" that takes on various accidental "forms" (obviously, "lightning" and "snake-like" also resonate with mythological and theological allusions, especially in a lecture by a classical scholar and Protestant minister, but this dissemination will not be pursued here). The most striking move in this passage may well be Schleiermacher's example, which initiates a discontinuous series of specifications and revisions, identifying the individual first with a national culture consisting of a literary canon ("the riches of language"; $\mathrm{cf}$. the international "treasures of foreign arts and scholarship" [p. 88]), then with a specifically literary, even scholarly appreciation of the Greek language ("measure and euphony"), and finally with a cognitive "power" that is "peculiarly his," selfexpressive and fundamentally self-determining.

The passage is a reminder that Schleiermacher is setting up the understanding of language associated with a particular national cultural elite as the standard by which language use is made intelligible and judged. Hence, in the case of foreignizing translation, "the reader of the translation will become the equal of the better reader of the original only when he is able first to acquire an impression of the particular spirit of the author as well as that of the language in the work" (p. 80). Yet the author-orientation in Schleiermacher's theory, his anthropomorphosis of translation from an intertextual to an inter- 
subjective relationship, psychologizes the translated text and thus masks its cultural and social determinations. This is the much criticized move in Schleiermacher's hermeneutics: he tends to evaporate the determinate nature of the text by articulating a two-fold interpretive process, both "grammatical" and "technical or psychological." ${ }^{\text {"16 }}$ A grammatical explanation of the objective "connection between the work and the language" combines with a psychological explanation of the subjective "connection between the work and the thought involved in it." Schleiermacher, however, sometimes collapses this distinction, as in his aphorisms on hermeneutics from 1809-1810, which refer to "combining the objective and subjective so that the interpreter can put himself 'inside' the author. ${ }^{17}$ In the case of German foreignizing translation, then, the translator enables the German-language reader to understand the individuality of the foreign author so as to identify with him, thereby concealing the transindividual, German-language ideologies - cultural (literary elitism), class (bourgeois minority), national ("German") - that mediate the foreignized representation of the foreign author in the translation. Such thinking about language and subjectivity is clearly more consistent with domesticating translation, oriented toward conformity with target-language cultural values, and so can do

16. For critiques of Schleiermacher's hermeneutics along these lines, see, for example, Richard E. Palmer, Hermeneutics: Interpretation Theory in Schleiermacher, Dilthey, Heidegger, and Gadamer (Evanston, Illinois, Northwestern University Press, 1969), pp. 91-94, and HansGeorge Gadamer, "The Problem of Language in Schleiermacher's Hermeneutic," trans. David E. Linge, in Schleiermacher as Contemporary, ed. Robert W. Funk (New York, Herder and Herder, 1970), pp. 68-84. Two expositions of Schleiermacher's hermeneutics which make clear but do not critique its individualism are H. Jackson Forstman, "The Understanding of Language by Friedrich Schlegel and Schleiermacher," Soundings, 51 (1968): pp. 146-165, and Peter Szondi, "Schleiermacher's Hermeneutics Today," On Textual Understanding and Other Essays, trans. Harvey Mendelsohn (Minneapolis, University of Minnesota Press, 1986), pp. 95-113. The next sentence in my text quotes from Szondi's exposition, p. 103.

17. Friedrich Schleiermacher, Hermeneutics: The Handwritten Manuscripts, ed. Heinz Kimmerle, trans. James Duke and Jack Forstman (Missoula, Montana, Scholars Press, 1977), p. 64. 
little to question the dominance of transparent discourse in translation today. On the contrary, Schleiermacher's psychologization of the text assumes transparency, the presence of the foreign author in the translation.

There is another kind of thinking in his lecture that runs counter to this idealist strain, even if impossibly caught in its tangles: a recognition of the cultural and social conditions of language and a projection of a translation practice which takes them into account instead of working to conceal them. Schleiermacher sees translation as an everyday fact of life, not merely an activity performed on literary and philosophical texts, but necessary for intersubjective understanding, active in the very process of communication, because language is determined by social differences: "even contemporaries who are not separated by dialects, but merely belong to different classes, which are not often linked through social intercourse and are far apart in education, often can understand each other only by means of a similar mediation" (p. 68). This observation clearly requires Schleiermacher to revise his nationalist concept of "the spirit of the language": he understands it as "the repository of a system of observations and shades of mood," but this is too monolithic and too psychologistic to admit the concept of "different classes," a social hierarchy of cultural discourses each so distinctively class-coded as to impede communication. Schleiermacher even finds it "inevitable that different opinions should develop as to" foreignizing translation strategies, "different schools, so to speak, will arise among the masters, and different parties among the audience as followers of those schools," but he ultimately individualizes the "different points of view," reducing them to the translator's consciousness: "each one in itself will always be of relative and subjective value only" (p. 81). It is social difference, however, that guides Schleiermacher's prescriptions for the foreignizing translator, for the invention of discursive peculiarities to signify the foreignness of the foreign text: the translator must reject the discourse that is used most widely in the target-language culture, the "colloquial" (p. 78; "alltäglich" $[T L$, p. 314]), refusing "the most universally appealing beauty each genre is capable of" in his language and instead risking the compassionate smile of "the greatest experts and masters who could not understand his laborious and ill-considered German if they did not supplement it with their Greek and Latin" (p. 79). Once again, the 
social difference marked by Schleiermacher's foreignizing translator runs between an educated elite and the uneducated masses: when the translator bends his language to a foreign likeness, he is not doing it with "each genre," "universally," but with literary and scholarly texts in Greek and Latin, so that only "experts and masters" can "understand" his deviant use of language. And yet, despite the questionable ideological determinations of Schleiermacher's lecture - its bourgeois individualism and cultural elitism, its Prussian nationalism and German universalism - it does contain the (inadvertent) suggestion that foreignizing translation can alter the social divisions figured in these ideologies, can promote cultural change through its work on the target language:

every freely thinking, mentally self-employed human being shapes his own language. For in what other way - except precisely by means of these influences - would it have developed and grown from its first raw state to its more perfect elaboration in scholarship and art? In this sense, therefore, it is the living power of the individual which creates new forms by means of the plastic material of language, at first only for the immediate purpose of communicating a passing consciousness; yet now more, now less of it remains behind in the language, is taken up by others, and reaches out, a shaping force. (p. 71)

This passage reverses its logic. At first language is taken to exist in an unmediated "raw state," worked by a transcendental subject who "shapes his own language," who is the origin of linguistic and cultural innovation and development. By the end, however, the determinate nature of language emerges as the "shaping force" of subjects. In the interval, the materiality of language is socialized: no longer "raw," it contains "new forms" invented by "the individual," but exceeding the function they were intended to serve, the communication of "consciousness," because they have been invented from pre-existing forms used by "others." This indicates that subjectivity is neither self-originating nor the origin of language and culture, that its cultural values (e.g. "scholarship and art") are pre-given and constantly reworked ("elaboration"), and that therefore the subject can be considered selfdetermining only insofar as it ranks these values - or revises them and 
alters an established ranking. The discursive innovations and deviations introduced by foreignizing translation are thus a potential threat to target-language cultural values, but they can perform their revisionary work only from within, developing translation strategies from the diverse discourses in the target language.

Schleiermacher's lecture provides the theoretical tools for conceptualizing a revolt against the valorization of transparent discourse in contemporary translation. But it does so by turning Berman's ethics of the cultural other into a politics of cultural difference. Schleiermacher makes clear the socially situated nature of cultural discourses by showing that what constitutes the foreign in foreignizing translation is never available in some unmediated form, entirely free of ethnocentrism. It is always an interpretation made by the translator, not necessarily open to every reader, gaining visibility and privileged only from a particular ideological standpoint in the target-language culture. Every step in the translation process - from the selection of foreign texts to the development and implementation of translation strategies to the editing and reviewing of translations - is mediated by the heterogeneous cultural values that circulate in the target language, always in some hierarchical order. The translator, who does his work with varying degrees of calculation, under continuous self-monitoring and often with active consultation of cultural rules and resources (from dictionaries and grammars to other texts, translation strategies, and translations, both canonical and marginal), may submit to or resist dominant values in the target language, with either course of action susceptible to ongoing redirection. Submission assumes an ideology of assimilation at work in the translation process, locating the same in a cultural other, domesticating the linguistic and cultural difference of the foreign text, pursuing a cultural narcissism that is imperialistic abroad and conservative, even reactionary, in maintaining canons at home. Resistance assumes an ideology of autonomy, locating the alien in a cultural other, foregrounding the linguistic and cultural differences of the source-language text through foreignizing strategies, pursuing cultural diversity so as to transform the hierarchy of cultural values in the target language. Resistance too can be imperialistic abroad, appropriating foreign texts to serve its own cultural political interests; but insofar as it resists values that exclude certain texts, it performs an act of cultural restoration which aims to question and possibly re-form, 
or simply smash the idea of, canons at home. Unable to avoid some degree of ethnocentrism in translation, we can nonetheless take sides in cultural political divisions to redirect it; we can develop foreignizing discourses that oppose the discourses of domestication in the target language.

Schleiermacher's concept of foreignizing translation constitutes a resistance to dominant cultural values in German at the turn of the nineteenth century. The foreign in foreignizing translation then meant a specific selection of foreign texts (literary, philosophical, scholarly) and a development of discursive peculiarities that opposed both French cultural hegemony, especially among the aristocracy, and the literary discourses favored by the largest segment of middle- and working-class readers. Schleiermacher's translation project depends on an idealist concept of literature that is at once elitist and nationalist, individualistic yet defined in opposition to capitalist economic practices: "the interpreter plies his trade in the field of commerce; the translator proper operates mainly in the fields of art and scholarship" (p. 68). It is this ideological ensemble that must be jettisoned in any revival of foreignizing translation to intervene against the contemporary ascendancy of transparent discourse. Today, transparency is the dominant discourse in poetry and prose, fiction and nonfiction, bestsellers and print journalism; and even if the electronic media have weakened the economic, political, and cultural hegemony of print in the post-World War II period, the idealist concept of literature that underwrites that discourse continues to enjoys considerable institutional power, housed not only in the academy and in the literary cultures of various educated elites, but in the publishing industry and the massaudience periodical press. The distinction that Schleiermacher perceived between the field of commerce and the fields of art and scholarship has been eroded (if it ever existed as more than a fiction designed to consolidate literature as a transcendental cultural concept): transparent discourse is eminently consumable in the contemporary cultural marketplace, which in turn influences publishing decisions to exclude discourses that resist transparency. Because foreignizing translation could constitute such a resistance, its ideological determinations in Schleiermacher may tempt some to regard any advocacy of it as an elitist cultural move, a theory and practice of translation specific to a minority. Yet the varied foreignizing efforts that have already been 
made suggest otherwise. They remain extremely sensitive to the literary qualities of the foreign text, but they are designed to do more than provide a basis for literary appreciation, which Schleiermacher saw as "the real aim of translation" (p. 87). Some English-language translators are selecting foreign texts and developing foreignizing strategies to intervene in cultural political divisions, serving a feminist agenda, for example, by challenging patriarchal representations of author and translator in the target-language culture. ${ }^{18}$ Foreignizing translation can also be made to serve an ideology of autonomy in a geocultural politics by seeking to redress the grossly unequal cultural exchanges between the hegemonic nations, particularly the United States, and their cultural others, particularly in the Third World, and by resisting - while possibly reforming - the canons that valorize transparent discourse and dictate domesticating translation. Here Schleiermacher is indispensable: since for him foreignizing translation aims to reproduce the play of signifiers in the foreign text, acknowledging that "the more closely the translation follows the turns taken by the original, the more foreign it will seem to the reader" (p. 78), he opposes the foregrounding of the signified by which fluent strategies produce the effect of transparency.

Both Schleiermacher and Berman are theorizing an approach to translation based on cultural resistance, and as they make plain, this is an approach that is specific to the German translation tradition, appearing initially in the late eighteenth century with the classical and romantic movements. The theory and practice of Anglo-American and French translation, in contrast, has been dominated by cultural submission, at least since D'Ablancourt and Denham, Dryden and Colardeau. ${ }^{19}$ Alternative approaches have been developed, of course,

18. See, for example, Barbara Godard, "Preface," in Nicole Brossard, Lovhers, trans. Barbara Godard (Montréal, Guemica, 1986), pp. 7-12, and Suzanne Jill Levine, "From 'Little Painted Lips' to Heartbreak Tango," in The Art of Translation: Voices from the Field, ed. Rosanna Warren (Boston, Northeastern University Press, 1989), pp. 30-46.

19. A. Berman, "La traduction et la lettre," pp. 49-50. T. R. Steiner clarifies, but without criticizing, the dependence of English translation theory on the French during the seventeenth century in his 
like the Victorian strategies of historicizing archaism (F. W. Newman, William Morris, Dante Gabriel Rossetti) and the modernist projects of discursive heterogeneity (Ezra Pound, Paul Blackburn) and homophony (Louis Zukofsky). ${ }^{20}$ For the most part, however, translators in England, the United States, and France have let their choice of foreign texts and their development of translation strategies conform to dominant cultural values in the target languages. The effects of this assimilationist ideology include, I want to suggest, not only the current prevalence of fluent translation strategies, but also the marginalization of texts in the history of translation which can yield alternative theories and practices - like Schleiermacher's lecture. With very few exceptions, contemporary theorists and practitioners of translation continue to neglect Schleiermacher, even though his lecture has long been recognized as a key "modern" statement in translation theory. Lefevere, for example, who prepared the first English translation of it in 1977, concludes that Schleiermacher's "requirement that the translation should 'give the feel' of the source language must [. . .] strike us increasingly as odd" (p. 67):

In effect, we are faced here with a not-illogical and very spirited defence of what we know now as "translationese" or, with another phrase: "static equivalence," and which is still

introduction to English Translation Theory, 1650-1800, ed. T. R. Steiner (Assen, Van Gorcum, 1975), especially pp. 13-25.

20. For Victorian and modemist translation, see Susan Bassnett-Maguire, Translation Studies (London and New York, Methuen, 1980), pp. 6772, Ronnie Apter, Digging for the Treasure: Translation after Pound (1984; rpt. New York, Paragon House, 1987), and Paul Mann, "Translating Zukofsky's Catullus," Translation Review, 21/22 (1986): pp. 3-9.

21. George Steiner has so far been the only translation theorist writing in English who recognizes the contemporary importance of Schleiermacher's lecture - but for rather different reasons from those set forth here and in Berman's work. See George Steiner, After Babel: Aspects of Language and Translation (London, Oxford, New York, Oxford University Press, 1974), p. 237 et passim, and Berman, L'Epreuve de l'étranger, pp. 248-249n. 
very much with us, in spite of the fact that most theoreticians would now subscribe to the concept of dynamic equivalence, which "aims at complete naturalness of expression and tries to relate the receptor to modes of behavior relevant within the context of his own culture." 22

Schleiermacher's concept of foreignizing translation seems odd to Lefevere only because the latter submits to the dominance of transparent discourse in contemporary translation - "complete naturalness of expression" - a dominance which coincides with the post-war emergence of the term "translationese" to designate unidiomatic language in a translation $(O E D)$. Lefevere approves of "dynamic equivalence," a concept that now, with the increasing recognition of Schleiermacher's contemporary importance, must be viewed as an egregious euphemism for the domesticating translation method and the cultural imperialism it conceals. Because this method is so culturally entrenched, Lefevere is unable to see that the detection of unidiomatic language, especially in literary texts, is culturally specific: what is unidiomatic in one cultural formation can be aesthetically effective in another. Lefevere's dismissive treatment of Schleiermacher is indicative of the conservatism that still characterizes translation today, for it hinders reflection on how translation can resist the questionable values that dominate Anglo-American and French culture. Schleiermacher, however, can indeed offer a way out.

22. André Lefevere, "German Translation Theory: Legacy and Relevance," Journal of European Studies, 11 (1981), pp. 9-17 (11). In this passage Lefevere is using Eugene Nida's concept of "equivalence," which is quoted from Nida, Toward a Science of Translating (Leiden, Brill, 1964). Berman indicates the complicity of Nida's theory with "l'impérialisme culturel nord-américain" in "La traduction et la lettre," p. 52. Lefevere has recently reaffirmed his conservative view of Schleiermacher's theory by asserting that "the second part of his famous maxim, 'move the author towards the reader,' [is] the only viable one": see Lefevere, "Translation: Its Genealogy in the West," in Translation, History and Culture, ed. Susan Bassnett and André Lefevere (London and New York, Pinter, 1990), pp. 14-28 (19). 